\title{
減圧下における水蒸気凝結現象を利用した固-液相 マイクロカプセルスラリー潜熱蓄熱材の採熱特性*
}

\author{
片山正敏*1, 稲葉 英 男*2, 堀部明彦*2 \\ 春 木 直 ${ }^{* 2}$, 真 鍋 健*3

\section{Latent Heat Release Characteristics of Solid-liquid Phase Change Heat Storage Microcapsule Slurry by Condensation Heat of Vapor under a Vacuum Condition} \\ Masatoshi KATAYAMA*4, Hideo INABA, Akihiko HORIBE, \\ Naoto HARUKI and Tsuyoshi MANABE \\ ${ }^{* 4}$ General Machinery \& Engineering Division, Takuma Co., Ltd., \\ 600-1 Kuze Tonoshiro-cho, Minami-ku, Kyoto, 600-8205 Japan

\begin{abstract}
Recently, studies have begun on a functional heat transfer medium using fine spherical microcapsules encapsulated with phase-change material and dispersed in water. This enables the medium to maintain fluidity whether the phase-change material is solid or liquid. The present study has clarified the laten-heat storage characteristics of microcapsule slurry by increasing its heat transfer coefficient with the help of evolved heat condensing of vapor from the slurry in heat storage. Paraffin wax with the melting point of $62^{\circ} \mathrm{C}$ was encapsulated into the fine microcapsules and used as a phasechange material. The cooling coil surface temperature and concentration of paraffin in the microcapsule slurry were selected as the experimental parameters. As a result, the non-dimensional correlation equations of the heat release completion time and heat transfer coefficient were derived in terms of non-dimensional parameters.
\end{abstract}

Key Words : Microcapsule slurry, Subcooled Boiling, Film Condensation, Phase Change Material, Heat Release, Latent Heat Storage

\begin{abstract}
1. 緒 言
エネルギー有効利用の分野において高効率利用とエ ネルギー貯蔵技術が最重要課題と考えられ, 熱需要と 供給の時間的, 空間的なミスマッチを解消する蓄熱技 術に関する様々な研究開発 ${ }^{(1)}$ が行われている. 融解潜 熱を利用する潜熱蓄熱は高密度エネルギ一貯蔵が可能 であり，相変化時には一定の温度で熱を取り出すこと が可能である. 特に, 夜間の余㮃電力を利用した氷蓄 熱システムは, 氷の融解潜熱を昼間の冷房空調に利用 されている. しかし, 暖房や給湯などに要求される中 温度領域での蓄熱に関しては顕熱型の温水蓄熱が主流 であり, 潜熱蓄熱の実用化例は少ない. 近年, 微小な 球状カプセルに潜熱蓄熱材を封入した潜熱蓄熱材を水
\end{abstract}

* 原稿受付 2003 年 5 月 15 日.

*1 正員, (株) タクマ( 601-8205 京都市南久世殿城町 600-1).

*2 正員, 岡山大学工学部 ( $300-8530$ 岡山市津島中 3-1-1).

*3 学生員, 岡山大学大学院.

E-mail : katayama@takuma.co.jp
に分散混合させたマイクロカプセルスラリー（以下ス ラリーと略する) のような機能性熱媒体 ${ }^{(2)(3)}$ が注目を浴 びている.これらはカプセル殼により潜熱蓄熱材が固 相時にも流動状態を保ち，管内搬送を可能にし，さら に，融点の異なる潜熱物質を蓄熱材に用いることによ り，様々な温度域での蓄熱が可能であることなどの利 点を有している. しかしながら,マイクロカプセルの分 散安定を図るためのカプセル径の微細化処理は, スラ リーの粘性抵抗の増大と熱伝達率の低下をもたらすこ とが知られている ${ }^{(4)}$. 筆者らは, このスラリーの伝熱 特性の低下を克服する手段として, 减圧下の過熱面状 でスラリーを構成する水を沸騰させマイクロカプセル 内潜熱蓄熱材の蓄熱特性（潜熱蓄熱材の融解）を報告

(5) した. 本研究では, 蓄熱されたスラリーを减圧下 で減圧沸騰させ，その蒸気の凝樎熱を取り出すことで スラリ一内潜熱蓄熱材からの採熱(潜熱蓄熱材の凝固) を促進させる試みを行うものである．実験は，スラリ 一の潜熱蓄熱材 (融点温度 $62^{\circ} \mathrm{C}$ ハパラフィン) と減圧 
下沸騰における蓄熱材濃度, 冷却熱交換器泠却面温度 を主要なパラメーターとして，その採熱特性を検討す るものである.

\section{主な記号}

アルファベット $C$ : マイクロカプセル含有濃度 [mass\%], $c_{\mathrm{p}}$ :比熱 $[\mathrm{kJ} / \mathrm{kgK}], D$ :蓄熱槽内径[m], $d_{\mathrm{m}}$ :ザウタ 一平均粒子径 $[\mu \mathrm{m}], d_{\mathrm{p}}:$ : イクロカプセルの粒子径 [ $\mu \mathrm{m}], F o$ :フーリエ数, $K$ :熱通過率 $\left[\mathrm{W} /\left(\mathrm{m}^{2} \cdot \mathrm{K}\right)\right], L$ : 潜熱量 $[\mathrm{kJ} / \mathrm{kg}], N u$ :ヌセルト数, $P$ :槽内圧力 $[\mathrm{kPa}], q$ :熱交換器外 表面における熱流束 $\left[\mathrm{W} / \mathrm{m}^{2}\right]$, Ste:ステファン数, $T$ :温度 $\left[{ }^{\circ} \mathrm{C}\right], t$ 時間 $[\mathrm{sec}], \Delta T$ :試料と熱交換器外表面間の温度 差 $\left.{ }^{\circ} \mathrm{C}\right], u$ :泠却水流速 $[\mathrm{m} / \mathrm{s}], Y a:$ ヤブ数, $z$ :液層高さ $[\mathrm{m}]$, $z / D$ :無次元液層高さ,

ギリシャ文字 $\rho:$ : 密度 $\left[\mathrm{kg} / \mathrm{m}^{3}\right], \mu$ :粘性係数 $[\mathrm{mPa} \cdot \mathrm{s}]$, $\lambda$ :熱伝導率 $[\mathrm{W} / \mathrm{mK}], a$ :温度伝導率 $\left[\mathrm{m}^{2} / \mathrm{s}\right], v$ :動粘性係 数 $\left[\mathrm{m}^{2} / \mathrm{s}\right]$

添字 0:初期状態, con:凝結, f:終了, fu:融解, in:冷却水入 口 L:液相, $m$ :試料, out:泠却水出口, $s$ :蒸気, $v$ : 気相, wm: 壁面平均

\section{2. マイクロカプセルスラリーの特徴及ひ物性}

本研究では，芯物質（以下，芯物質は全て潜熱蓄熱 材と略する）として粒子径約 $1 \mu \mathrm{m}$ のメラミン樹脂製 カプセル内に蛼点が $62^{\circ} \mathrm{C}$ の-パラフィンを封入し，そ のカプセルを水に分散混合 ( $C=10 \sim 40 \mathrm{mass} \%)$ させた ものを使用した.カプセルを均一に分散させるため $2 \%$ 程度の界面活性剂を添加されている. スラリーは牛乳 のような白く濁った液体である. 粒子径の平均はザウ ター平均粒子径より算出し, $d_{m}=0.71 \mu \mathrm{m}$ でありカプ セルの款厚さは, 約 $25 \mathrm{~nm}$ と薄く熱抵抗は小さいもの と思われる.以下に測定したスラリーの物性值を示す. 各物性の測定方法は，著者らの報告(5)に記述されてい るので, その記述は避ける.

\section{$2 \cdot 1$ 潜熱量}

図 1 に示差走查熱量計(DSC)により,カプセル内の潜 熱蓄熱材の潜熱量を測定した試料温度と潜熱量の関係 を示す. 融解過程において約 $55\left[{ }^{\circ} \mathrm{C}\right]$ で相転移, 約 $65\left[^{\circ} \mathrm{C}\right]$ で融解潜熱のピークを有している. 一方, 凝固過程に おいては, 約 50,60[ㄷ]で 2 つのピークを有しており， 約 $50\left[{ }^{\circ} \mathrm{C}\right]$ で多くの熱量を放出していることから，凝固 過程において過冷却現象が生じていると考えられる.

\section{$2 \cdot 2$ 密度}

図 2 に加熱時におけるスラリーの密度 $\rho$ の変化を示
す. 密度は相転移および相変化前後で大きく変化して おり, マイクロカプセル含有港度の増加に伴い, 密度 が减少する傾向を示すが相転移および相変化中 $\left(T_{\mathrm{m}}=55 \sim 65\left[{ }^{\circ} \mathrm{C}\right]\right)$ 以外の範囲においては, スラリーの 密度はほぼ水の密度と同じ傾きで䋸やかに減少してい る。

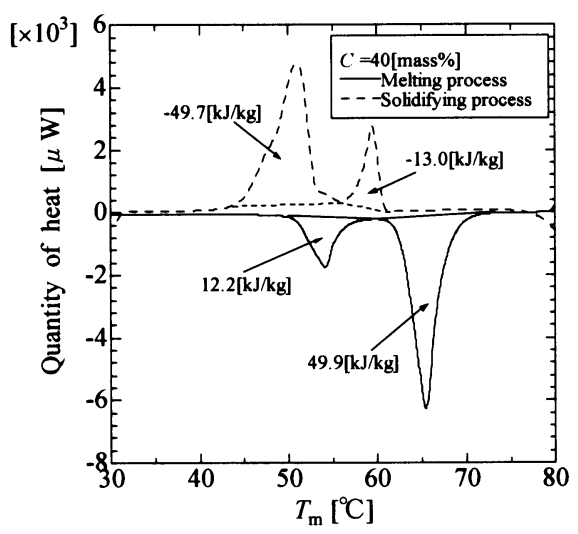

Fig.1 Latent heat of the microcapsule slurry

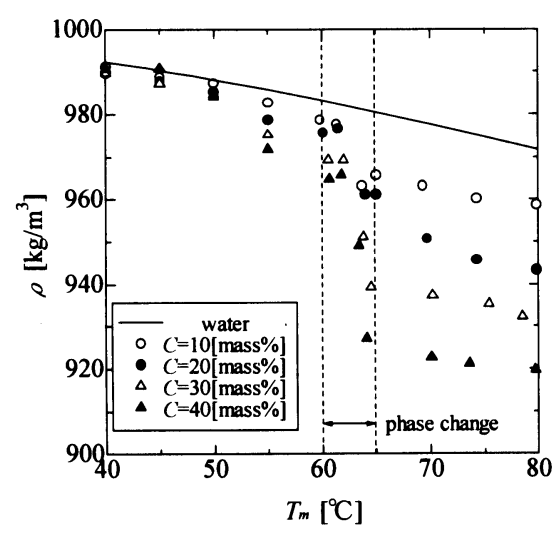

Fig.2 Density of microcapsule slurry

$2 \cdot 3$ 粘性係数

本実験で用いたスラリーは，せん断速度 $\gamma$ に対する せん断応力 $\tau$ の関係はほぼ直線的に比例(5)しており， ニュートン流体であると考えられる.

図 3 に試料温度と粘性係数の関係を示す．潜熱蓄熱 材湿度 Cの増加に伴い粘性係数は急激に増加すること がわかる.

\section{$2 \cdot 4$ 熱伝導率}

非定常細線加熱法により測定した試料の熱伝導率を

図 4 に示す. 試料の熱伝導率は温度の増加に伴い増 
加しているが，相変化時に大きく減少することがわか る.これは潜熱蓄熱材の相変化つまり融解によって潜 熱蓄熱材の熱伝導率が減少したと考えられる。潜熱蓄 熱材浱度 $C$ 増加に伴い，試料中に含まれる潜熱体の 割合が増加するため試料の熱伝導率が減少することが わかる。

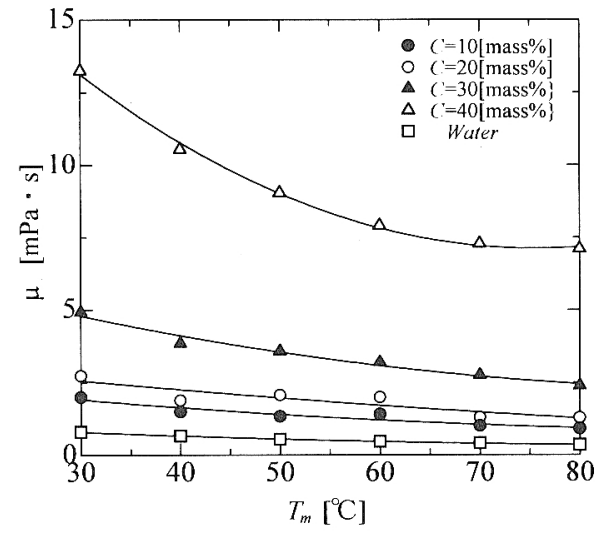

Fig.3 Viscosity of microcapsule slurry

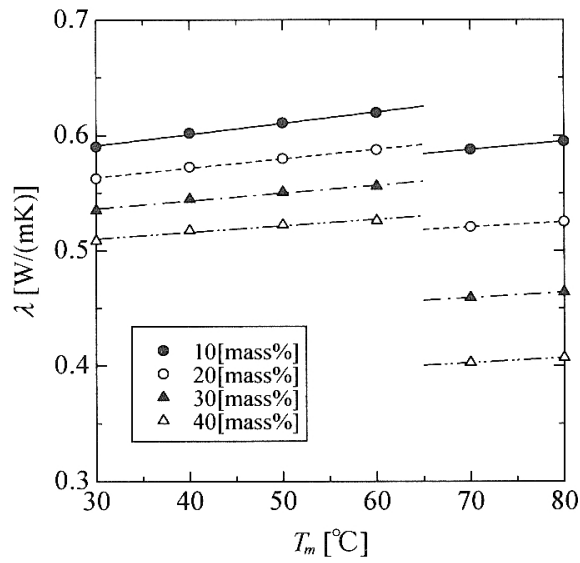

Fig.4 Thermal conductivity of microcapsule slurry

\section{3. 実験装置および実験方法}

実験装置の概略を図 5 に示す。本実験装置は主に試 料スラリーの充填および蓄熱を行うための蓄熱槽, 採 熱実験により試料を冷却するための熱交換器と冷却水 を冷却する冷却装置そして測定装置から構成されてい る.

図 6 は，蓄熱槽の詳細図であり，蓄熱槽は内径 $266[\mathrm{~mm}]$, 高さ $400[\mathrm{~mm}]$, 肉厚 $2[\mathrm{~mm}]$ のステンレス製円 筒容器であり, 蓄熱槽上部と下部は外径 $350[\mathrm{~mm}]$ の真

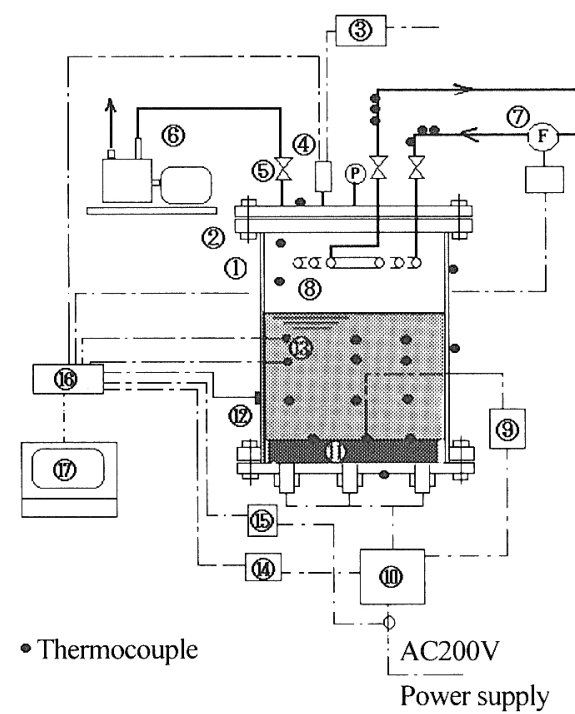

(1) Glass Vessel (10)Electric power controller (2) Vacuum flange (11) Heater (3) Electric power supply (4) Pressure gage (12) Heat flux sensor (13) Thermocouples (5) Vacuum valve (14) Voltage transducer (6) Vacuum pump (7) Flow meter (8) Cooling coil (15)Current transducer (16) Measuring instrument (17) Personal computer

(9) Temperature controller

Fig.5 Test equipment

空フランジで蓄熱槽内を真空状態に保つために，蓄熱 槽上下のフランジ部は，O-リングにてシールしている. 加熱源として蓄熱槽下部に上面を平面加熱面とした 円筒容器（直径 $240[\mathrm{~mm}] \times$ 高さ $40[\mathrm{~mm}]$ ）内に直径 $4.0[\mathrm{~mm}]$ のステンレス管内にニクロム線を充填したシ ースヒーター $1.5[\mathrm{~kW}] \times 4$ 本を渦巻状に多段に設置し た，蓄熱槽内の熱を採熱するため，上部フランジ面に 伝熱管（銅管外形 $\phi 6.0[\mathrm{~mm}] \times$ 肉厚 $1.0[\mathrm{~mm}] \times$ 長さ $870[\mathrm{~mm}])$ を渦巻状に設置し, 外部への取り出しは真 空を維持するためシリコンゴム栓を貫通させシールを 行った，蓄熱槽内の温度は，各位置加挿入された $\mathrm{T}$ 型熱電対（シース径 $\phi 1.0 \mathrm{~mm}$, 測定精度 $\pm 0.2^{\circ} \mathrm{C}$ ) 使用 し, スラリー層内の高さ方向において液層高さ(スラリ 一層高さ) $z$ に対する $1 ， 5 ， 9$ 割の位置と同様の配置で 蓄熱槽周方向に4ヶ所配置し, 計 12 本の熱電対を設け, 蒸気部には，高さ $300[\mathrm{~mm}]$ の位置で蓄熱槽周方向に 4 ヶ所, 装置外周表面 4 ヶ所, 外気温度, 熱交換器管内 の入口に 3 ヶ所, 出口に 3 ヶ所の合計 26 本と $\mathrm{K}$ 型熱 電対（シース径 $\phi 0.5 \mathrm{~mm}$, 測定精度 $\pm 0.1^{\circ} \mathrm{C}$ ）にて, 熱 交換器の長さ方向に225，480，670[mm]に3ヶ所，管 
周方向に上部を $0^{\circ}$ として時計方向に $0^{\circ}, 90^{\circ}, 180^{\circ}$ に3 ケ所の計 9 ケ所管表面温度を測定した. 内部圧力 はデジタル圧力センサー(精度 $\pm 0.5 \mathrm{kPa})$ にて測定し, 蓄熱槽から外部への放熱損失は容器の上部, 側部（蒸 気部, 溶液部)，底部の 4 ヶ所に取り付けられた熱流束

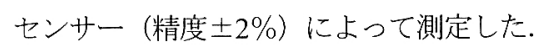

各熱電対, 圧力計, 熱流束センサーからの信号は, 測定間隔 $t=10$ 秒毎にデーターロガーを介して自動測 定した.

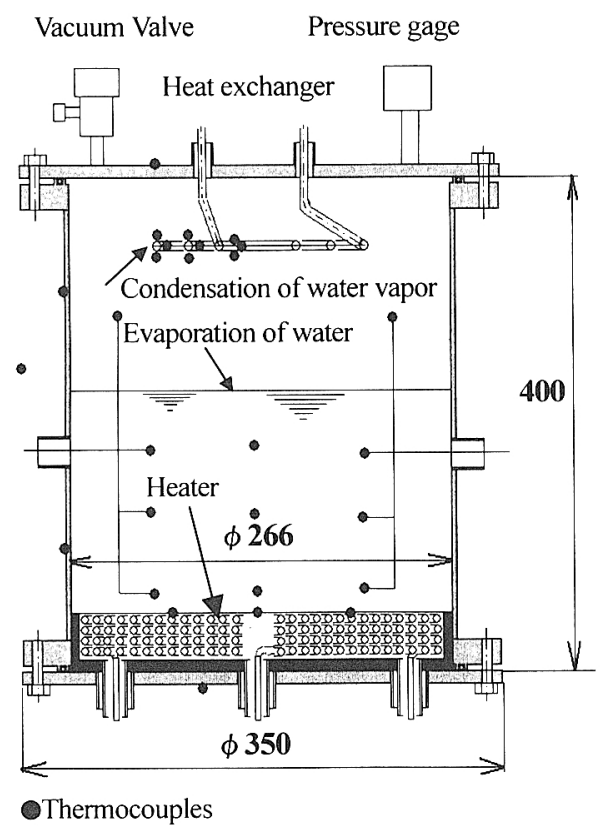

Fig.6 Heat storage tank

本放熱実験では，蓄熱槽内に一定濃度のスラリーを 規定量槽内に入れ，上部真空フランジを取り付けた後， 真空ポンプより内部を真空にした. 溶液内の溶存空気 を除去するため，一度ヒーターで試料を加熱し再び真 空ポンプにて抽気を行い, 容器内の溶存空気を完全に 除去した後, 真空バルブを閉じ, 水分の蒸発に伴う溶 液濃度の変化をなくすため実験終了まで真空ポンプを 作動せずテストを行った，不凝縮性ガスによる凝縮熱 伝達の影響を軽減寸るため槽内への空気混入量を約 $30[\mathrm{~Pa} / \mathrm{h}]$ 以下にして実験を行った.

実験開始前に試料温度を所定温度に調整した後，熱 交換器内に冷却水 $\left(T_{\mathrm{in}}=10 \sim 30\left[{ }^{\circ} \mathrm{C}\right]\right)$ 老流入させ, 試料中 の潜熱体が完全に凝固したと考えられる試料温度 $\left(T_{\mathrm{m}}=40\left[{ }^{\circ} \mathrm{C}\right]\right)$ に達した時点で終了した。 なお，実験パ ラメーターとして冷却水流速 $u[\mathrm{~m} / \mathrm{s}]$, 冷却水入口温度
$T_{\text {in }}\left[{ }^{\circ} \mathrm{C}\right]$, マイクロカプセル含有濃度 $C[$ mass \%], 液層高 さ $z[\mathrm{~mm}]$ を変化させて実験を行った. スラリ一中の水 の沸腾現象は，内部が観察できる耐熱ガラス (内径 $\phi$ $175[\mathrm{~mm}] \times$ 高さ $240[\mathrm{~mm}])$ の円筒形 ${ }^{(5)}$ で観察及びデジ タルビデオにて撮影を行った.

\section{4. 実験結果}

$4 \cdot 1$ 温度および圧力の経時変化

図 7 はスラリーの採熱実験における各部温度および 槽内圧力の経時変化(実験条件: 冷却水流速 $u=0.4[\mathrm{~m} / \mathrm{s}]$, 冷却水入口温度 $T_{\mathrm{in}}=10\left[{ }^{\circ} \mathrm{C}\right]$, スラリー濃度 $C=40[$ mass \%], 液層高さ $z=90[\mathrm{~mm}])$ である. 図 7 より, 実験開始から スラリ一層内温度(12 ケ所)測定位置によっての温度 差はほとんどなく一定である. 装置からの熱口スは, 総採熱量の約 $1 \%$ で無視できる程度であった.

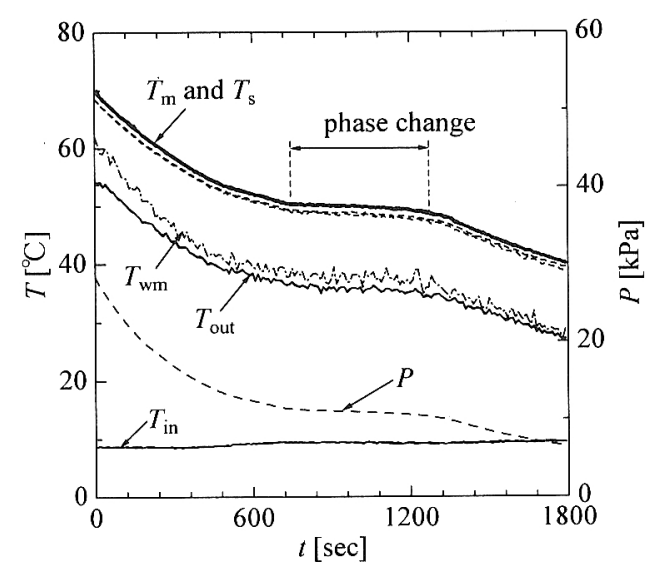

Fig.7 Time history of $T$ and $P(C=40[$ mass\% $])$

これは, 熱交換器伝熱面表面での凝縮により槽内圧 力低下が起こりスラリー層内で激しい沸騰に伴う擋汼 効果により, 層内温度の均一化が図られたことによる. スラリー温度 $T_{\mathrm{m}}$ と蒸気温度 $T_{\mathrm{s}}$ および彾却水出口温度 $T_{\text {out }}$ は約 700[sec]までは単調に減少し, 約 700 1200[sec] では，ほぼ一定值をとることから，カプセル内潜熱蓄 熱材の凝固による潜熱の影響が確認でき潜熱材の融点 が 62 [ $\left.{ }^{\circ} \mathrm{C}\right]$ であことから過冷却の影響が確認できる. 一方, 熱交換器外表面平均温度 $T_{\mathrm{wm}}$ は, $T_{\mathrm{m}}, T_{\mathrm{s}}, T_{\text {out }}$ 之同様の傾向を示寸が, 熱交換器表面に生じる凝縮液 の膜厚や離脱の影響で激しい温度変動が生じているこ とがわかる：槽内圧力 $P$ は， $T_{\mathrm{s}}$ に対応した傾向を示し ている. 図 8(a)〜(c)に図7，の採熱実験に刘応した無気 部とスラリ一層部の可視化写真を示す. 実験開始直後 ではスラリー層部から発生した気泡群が気相間に滞在 
しており，時間の経過(b) $t=240 \mathrm{sec}$, (c) $t=720 \mathrm{sec}$ と共 に気泡群の高さが減少している.

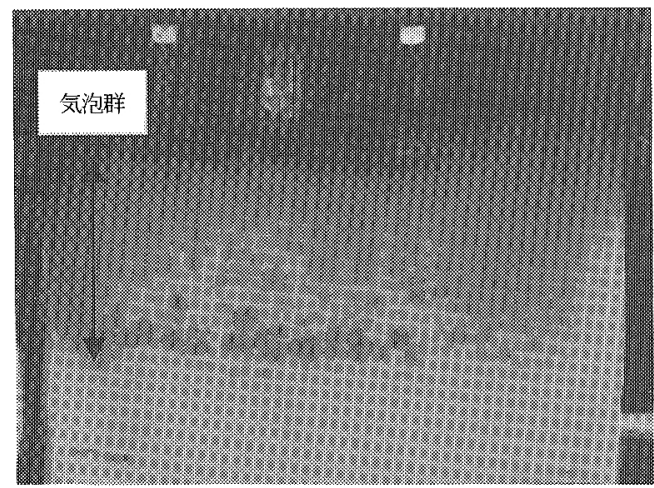

(a). $(t=5[\mathrm{sec}])$

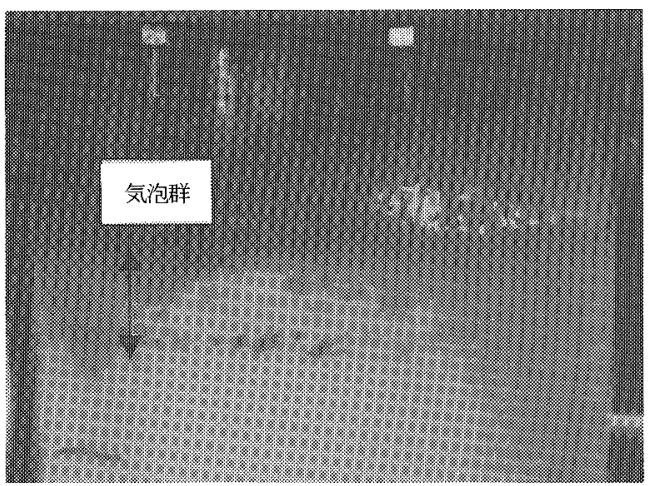

(b). $(t=240[\mathrm{sec}])$

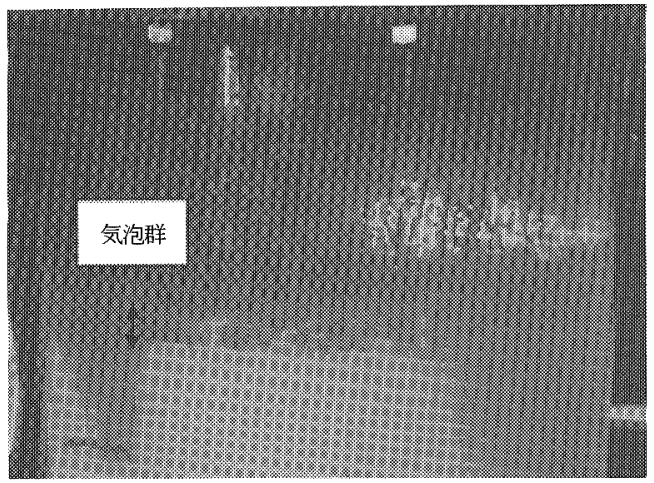

(c). $(t=720[\mathrm{sec}])$

Fig. 8 Chronological Changes in Boiling Behavior

これは，実験初期において熱移動の駆動力であるスラ リ一層と熱交換器外表面管の温度差（スラリー温度に 相当する飽和圧力と蒸気部圧力の圧力差) が大きいた め，スラリー層部からの気泡の発生量が多く，またス
ラリーの粘性の影響により気泡が消滅せず，気液界面 で気泡群となって存在し，時間の経過すなわち駆動力 の減少に伴い気泡層の高さが低くなるものと考えられ る.なお，各部温度および槽内内圧力の経時変化は実 験パラメーター (スラリー濃度, 泠却水入口温度)に よって実験終了時間が変化するものの，各温度，圧力 は同じ傾向を示した。

4・2マイクロカプセルスラリー層からの熱移動

$4 \cdot 2 \cdot 1$ 熱通過率

図 9 にスラリー層から沸騰と凝縮現象を介して熱交 換器外表面への熱移動の総括熱伝達率を示す。試料加 ら熱交換器外表面間における実験中の時間平均した総 括熱通過率 $K_{\mathrm{m}}$ を次式(1)のように定義した. 熱流束 $q$ は冷却水のエンタルピー上昇から算出される交換熱量 を熱交換器の外表面積 $\left(0.0164 \mathrm{~m}^{2}\right)$ により求めた. 図中の 一点鎖線は $\Delta T, K_{\mathrm{m}}$ の各データーの傾向を示す.

ここで，Kは実験中における熱通過率である。

$$
\begin{aligned}
K_{m} & =\frac{1}{t_{f}-t_{0}} \int_{t_{0}}^{t_{f}} K d t \quad K=\frac{q}{\Delta T} \\
t_{o} & =\text { 放熱開始時間, } t_{f}=\text { 潜熱放熱完了時間 }
\end{aligned}
$$

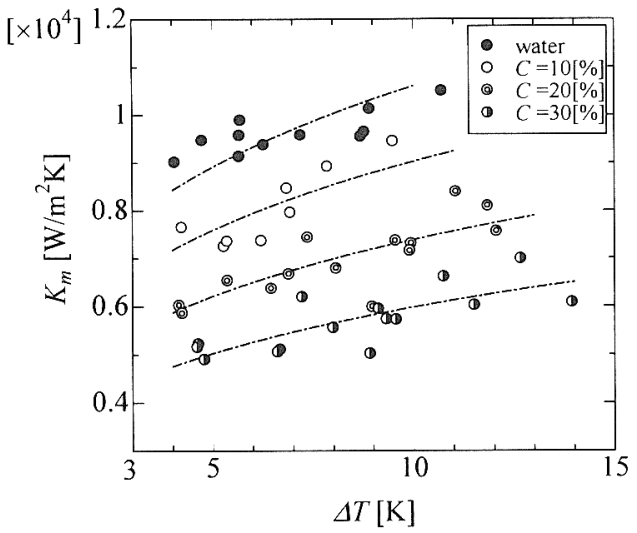

Fig.9 Coefficient of overall heat transmission

スラリーと熱交換器外表面温度間の温度差 $\Delta T$ の増 加に伴い， $K_{\mathrm{m}}$ が増加することがわかる.

これは，熱移動の駆動力であるスラリーと熱交換器 外表面管の温度差（スラリー温度に相当する飽和圧力 と蒸気部圧力の圧力差）が増加しスラリ一液層内から の水蒸気発生量が増大寸ることによって凝縮が促進さ れと考えられる. また, マイクロカプセル含有濃度 $C$ の増加に伴い $K_{\mathrm{m}}$ が減少している. 
これは，スラリー浱度 $C$ の増加に伴い，スラリー内 における水分量は减少し，スラリーの粘性が増えマイ クロカプセルから水への熱抵抗が增加し，スラリー内 の気泡発生が抑制されたと考えられる.

\section{$4 \cdot 2 \cdot 2$ 採熱完了時間}

スラリー温度と熱交換器外表面温度差 $\Delta T$ と採熱時 間 $t_{\mathrm{f}}$ の関係を図 10 に示す.

$t_{\mathrm{f}}$ は, 交換熱量が初期スラリー温度 $T_{\mathrm{m} 0}=70\left[{ }^{\circ} \mathrm{C}\right]$ からカ プセル内潜熱蓄熱材の凝固が終了した完了温度 $T_{\mathrm{f}}=43\left[{ }^{\circ} \mathrm{C}\right]$ までの理論採熱量 $Q$ に達した時間と定義した. この $T_{\mathrm{f}}=43^{\circ} \mathrm{C}$ は, 図 1 の DSC 曲線に基づいて潜熱蓄熱 材の過冷却後, 凝固する最低温度である. $t_{\mathrm{f}}$ は熱駆動 力 $\Delta T$ の増加に伴い减少する傾向を示す.

これは，単位時間あたりに移動する熱量が増加する ことおよび $K_{\mathrm{m}}$ が増加し，結果として採熱完了時間の 短縮となる. 一方, スラリー莀度 $C$ の増加は, 理論採 熱量 $Q$ が増大するため, $t_{\mathrm{f}}$ は增加する傾向を示す.

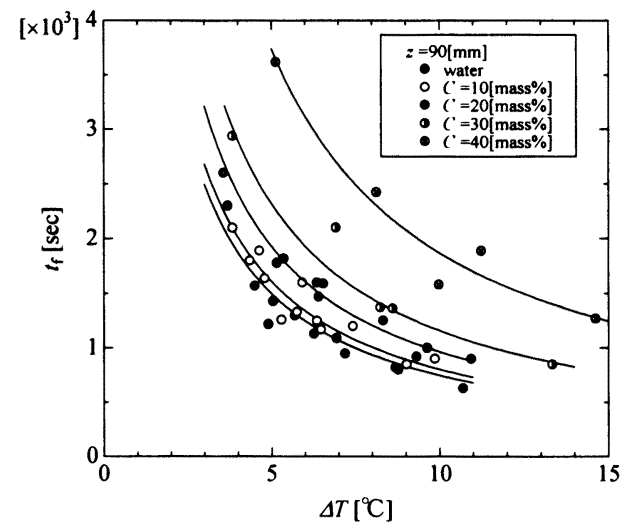

Fig.10 Relationship between $t_{\mathrm{f}}$ and $\Delta T$

\section{5. 熱伝達率及び採熱時間の整理}

潜熱蓄熱材の相変化 (凝固) におけるスラリー $(C=10$ 〜 40\%[mass\%]) 層から熱交換器外表面における熱伝達 率 K⿱ 終了する採熱時間 $t_{\mathrm{f}}$ に対する無次元整理式の誘導を以 下に試みる。

本研究での平均熱通過率として(2)に示すヌセルト 数 $\mathrm{Nu}$, 採熱時間の無次元数として文献(5) に基づいた 式(3) で示すフーリエ数 $F o_{\mathrm{f}}$, 潜熱蓄熱材浱度による潜 熱量の変化についての式(4) で示すステファン数 Ste, 水蒸気の凝固熱と過熱度 $\Delta T$ (熱駆動力) の変化につい ての式(5)で示すヤコブ数 $Y a$, 潜熱蓄熱材の量を無次元 液層高さ $z / D$ 導入する. それぞれの無次元数について
は，以下のように定義する.

$$
\begin{aligned}
& N u=\frac{K_{m} D}{\lambda} \\
& F o_{f}=\frac{t_{f} a}{D^{2}} \\
& \text { Ste }=\frac{\left(T_{m f}-T_{m 0}\right) c_{p m}}{L_{f u}} \\
& Y a=\frac{\rho_{L} c_{p L} \Delta T}{\rho_{V} L_{c o n}}
\end{aligned}
$$

$Y a$ 数の温度差は, スラリー温度と熱交換器外表面温 度差を, Ste 数の温度差には, スラリーの実験開始温度 と終了温度差とした. 式(2)〜(4)における諸物性值には, 実験開始温度 $\left(T_{\mathrm{m} 0}=70\left[{ }^{\circ} \mathrm{C}\right]\right)$ から実験終了温度 $\left(T_{\mathrm{m} f}=43\left[{ }^{\circ} \mathrm{C}\right]\right)$ までのスラリーの物性值の積分平均値を, 式(5)の分子の物性值は, スラリーに対するもの, 分母 は, 飽和水蒸気の物性値を用いた.

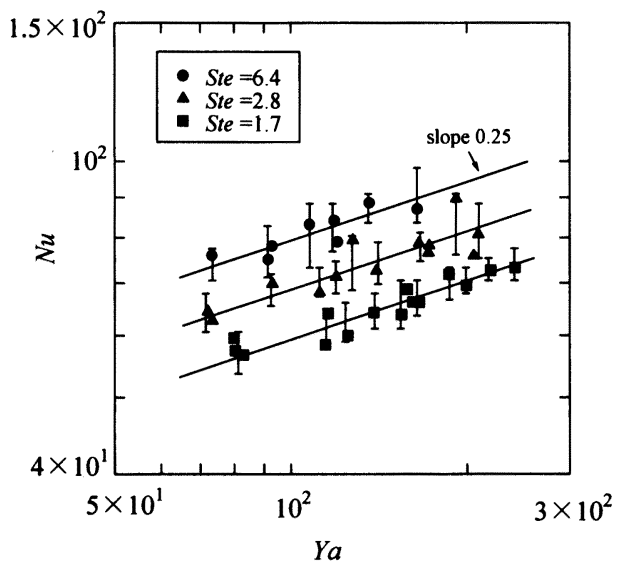

Fig.11 Relationship between $\mathrm{Nu}$ and $\mathrm{Ya}$

図 11 にヤコブ数 $Y a$ と $N u$ 数の関係を示す. $Y a$ 数の 増加に伴い $N u$ 数が増加している. $Y a$ 数の増大は, 熱 駆動力 $\Delta T$ の増大を意味し, 蓄熱槽内スラリー層内の 気泡径および気泡発生数を増加し，その伝熱量の増大 から, $\mathrm{Nu}$ 数の増加となる. $\mathrm{Nu}$ 数は $\mathrm{Ya}$ 数の 0.25 乗に 比例することがわかる.

図 12 にステファン数 Ste と $\mathrm{Nu}$ 数の関係を示す. Ste 数の增加に伴い $N u$ 数が増加していることが確認でき る. これは, Ste 数の増加, 主に潜熱蓄熱材漕度 $C$ の減 数の増加に伴い $N u$ 数が増加していることが確認でき 
る.

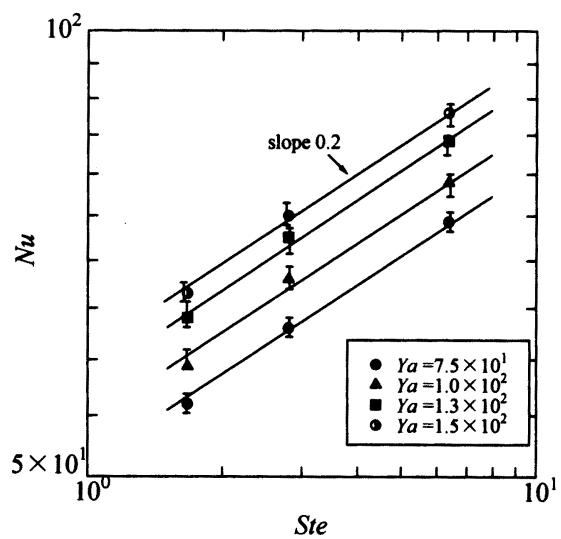

Fig.12 Relationship between $\mathrm{Nu}$ and $\mathrm{Ste}$

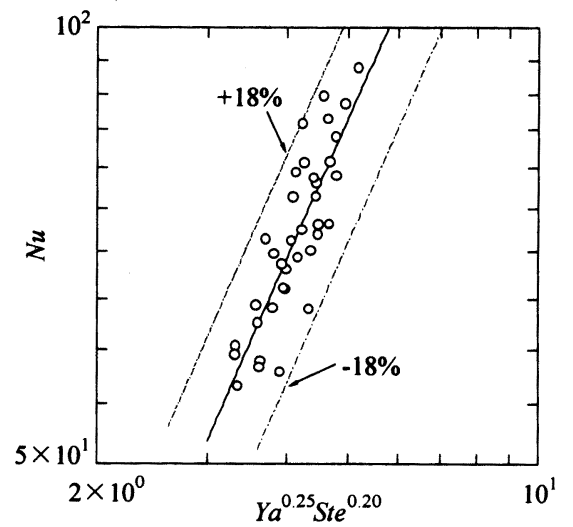

Fig.13 General correlation system on the $N u$ number

これは, Ste 数の増加, 主に潜熱蓄熱材濃度 Cの減少を 意味し, 漘度 $C$ の減少は, スラリー粘性の低下となり, 気泡による擋汼効果が増大するために, $N u$ 数の増加と なる. $N u$ 数は Ste 数の 0.2 乗に比例する関係があるこ とがわかる.図 12 中のプロット点は最小二乗法で求め た整理式から外挿した. なお, $N u$ 数に対する無次元液 層高さ $z / D$ の影響は今回の実験範囲においてほとんど 影響ないことを確認している.

$$
N u=17 \times Y a^{0.25} \text { Ste }^{0.2}
$$

上記の関係から，管外直径 $6 \mathrm{~mm}$, 管ピッチ $10 \mathrm{~mm}$ の 渦巻状単一水平円管外表面の $N u$ 数に影響を及ぼす $Y a$ 数と Ste 数の積に関する一般整理式を最小二乗法より 整理すると，式(6)のような無次元整理式が導出される.
図 13 が $\mathrm{Nu}$ 数に関する一般整理式と実駼值の值を示し たもので, 平均相対誤差士 $18 \%$ 以内で一致する結果を 得た. 上式の適用範囲は $Y_{a}=7.2 \times 10^{1} \sim 2.4 \times 10^{2}, S t e=1.7$ 〜6.4である.

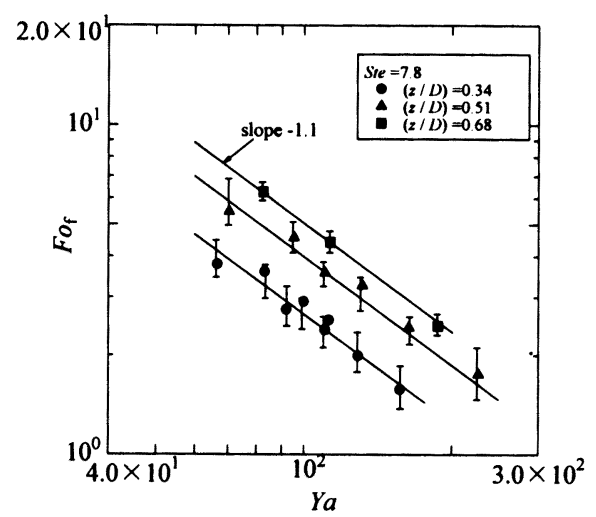

Fig. 14 Relationship between $\mathrm{Fo}_{\mathrm{f}}$ and $\mathrm{Ya}$

次に，採熱時間 $t_{\mathrm{f}}$ に関して無次元化を行い一般整理 式の導出を試みる.

図 14 は $Y a$ 数と $F o_{\mathrm{f}}$ 数の関係を示したものである. $Y a$ 数の増加に対して $F o_{\mathrm{f}}$ 数が减少しており, $Y a$ 数の增 大は, 主に熱駆動力 $\Delta T$ の增大を意味しており, 発生 する蒸気泡の増加をもたらし，その擋汼効果などによ り, 採熱時間の短縮となる. 図 14 より, $\mathrm{Fo}_{\mathrm{f}}$ 数が $\mathrm{Ya}$ 数の-1.1 乗に比例する関係にあることがわかる.

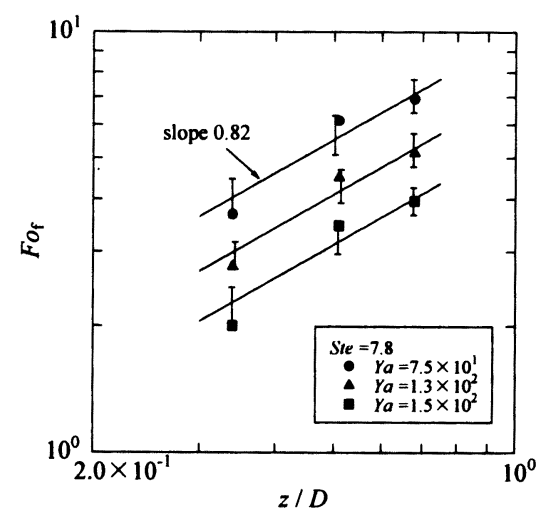

Fig. 15 Relationship between $F o_{\mathrm{f}}$ and $z / D$

図 15 は無次元層高さ $z / D$ と For 数の関係を示したも のである. $z / D$ の增加に対して $F o_{\mathrm{f}}$ 数が増加しているこ とがわかる. 本実験における槽内径 $D$ の值は一定とし た場合，z/Dについての変化は液層高さによるもので ある. この z/Dの增加はスラリー量の増加となり，そ 
の採熱量が増加することから $F o_{\mathrm{f}}$ 数が増加している. 図 15 より $F \mathrm{O}_{\mathrm{f}}$ 数は $z / D$ 数の 0.82 乗で比例する関係にあ ることがわかる.図 15 中のプロット点は最小二乗法で 求めた整理式から外挿した。

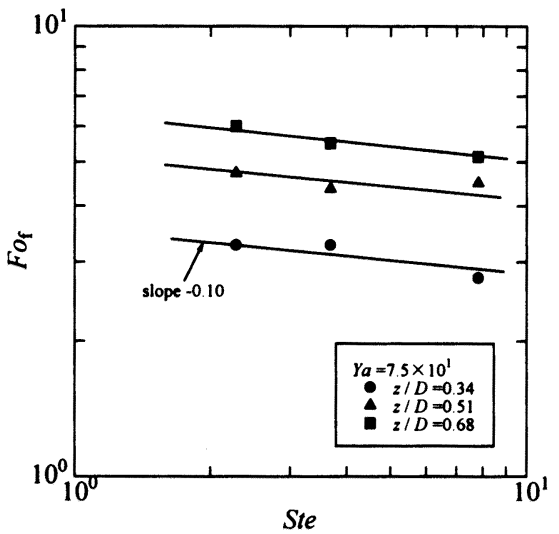

Fig. 16 The relationship between $S t e$ and $\mathrm{Fo}_{\mathrm{f}}$ number

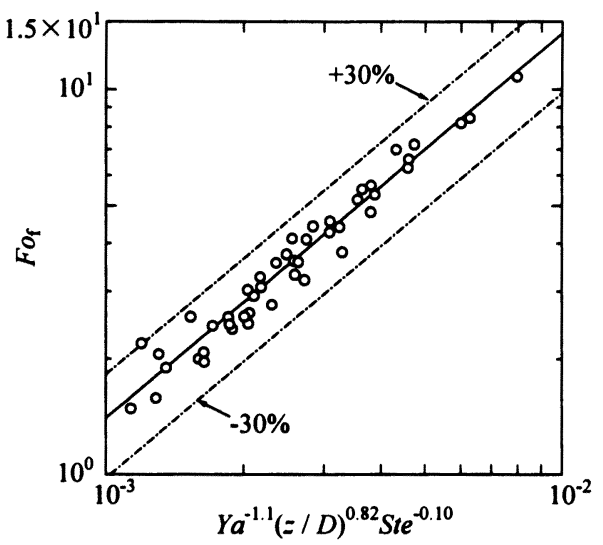

Fig. 17 General correlation of $F_{\mathrm{f}}$ to other parameters

図 16 はSte 数と $F O_{\mathrm{f}}$ 数の関係を示したものである. Ste 数の増加により $F_{\mathrm{f}}$ 数が低下しているが, 潜熱蓄熱 材浱度 $C$ の減少すなわち理論採熱量の堿少および粘性 の低下に伴う気泡摚汼効果の増大により潜熱蓄熱材の 凝固による採熱時間の短縮 $\left(F a_{\mathrm{f}}\right.$ 数が低下) をもたらし たものである. $F o_{\mathrm{f}}$ 数は Ste 数の-0.10 乗に比例する関 係があることがわかる．上記の関係から For 数に影翠 を及ぼす $Y a$ 数と $z / D$ およびSte 数の積に関する一般整 理式を最小二乗法より整理すると，次式(7)のような無 次元整理式が導出される.

$F o_{f}=1.4 \times 10^{3} \mathrm{Ya}^{-1.1}(z / D)^{0.82} \mathrm{Ste}^{-0.10}$
上式の適用範囲は, $Y a=7.2 \times 10^{1} \sim 2.4 \times 10^{2}$, $(z / D)=0.34 \sim 0.68$, Ste $=2.3 \sim 7.8, D=0.175 \sim 0.266 \mathrm{~m}$ であ る. なお, 蓄熱槽内直径 $D=0.175 \mathrm{~m}$ の実験は, 別の実 験装置 (5) で行ったものである. 図 17 が $F o_{\mathrm{f}}$ 数の整理 式と実験値の関係を示したもので, 最大偏差 $30 \%$ で 致する結果を得た。

\section{6. あとがき}

パラフィン系潜熱蓄熱材を充填したマイクロカプ セルスラリーを大気圧以下の真空状態で蓄熱した後, 熱を取り出す採熱時の熱伝達率や潜熱蓄熱材の凝固に よる相変化時間との関係を実験的に検討し, 次の結論 を得た。

(1) 採熱時におけるマイクロカプセルスラリーの減圧 下での沸騰現象は，潜熱蓄熱材に過冷却現象が生じる が, 液層部内では強い摚汼作用により均一な温度分布 を形成し, 潜熱蓄熱材の凝固潜熱の放出に伴って, 比 較的一定温度の熱抽出が効率良く行われることが可能 であることを確認した. さらに，可視化実験により放 熱時の液層部の沸騰擋汼による挙動を観察した.

（2）蓄熱槽内の熱移動では, マイクロカプセルスラリー から熱交換器外表面間の熱通過率について検討を行い， 浱度が増大するにつれ熱通過率が減少した。これはス ラリーの粘性が増えスラリー内の気泡発生が抑制され たと考えられる. 実験的に得られた熱通過率に関して 無次元化を行い，一般整理式の誘尊した.

(3) 潜熱蓄熱材の採熱完了時間においては, マイクロカ プセルスラリーと熱交換器外表面間の温度差に大きな 影㗽をうけることが判明した。この採熱時間に関して 無次元化を行い，一般整理式を誘導した.

\section{考支献}

(1)小関多賀美,竹田晴信,飯嶋和明,村井正光,松藤久良, 水素吸蔵合金を用いた蓄熱システムの開発,機 論,67-662,B(2001),170-178

(2)稲莱英男,機能性熱流体の現状と将来, 日本機械学 誌,98-925(1995),999-1000

(3)稲葉英男,金明俊,堀部明彦,等熱流束加熱を受ける円 管内を流動する潜熱マイクロカプセル混合水の融解伝 熱特性,日本冷凍空調学会論文,19-1(2002),13-22

(4)稲葉英男,金明俊,堀部明彦,等温冷却壁を有する円管 内を流動する潜熱マイクロカプセル混合水の蓄冷熱特 性,機論,68-665,B(2002),161-168

(5)稲葉英男,片山正敏,堀部明彦,春木直人,兵鍋健,减圧 下の沸騰状態での固一液相マイクロカプセルスラリー の潜熱蓄熱特性,日本冷凍空調学会論,20-1(2003),37-47 